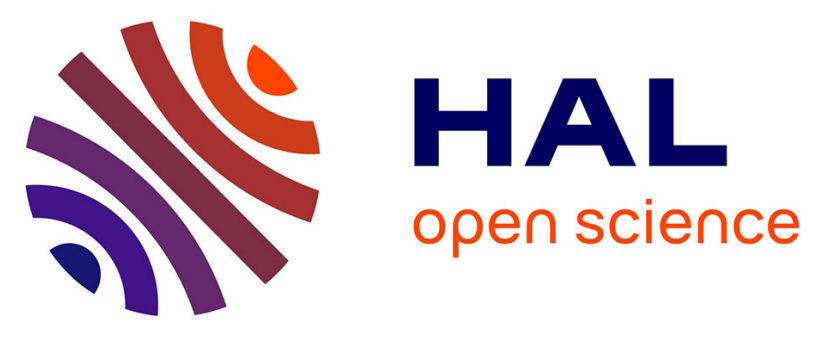

\title{
Reply to: Altered Calcium in Ciliary Dysfunction: Potential Role of ER Stress and Ciliophagy
}

Aurélie Petit, Lucie Knabe, Kamel Khelloufi, Myriam Jory, Delphine Gras, Yann Cabon, Malcolm Begg, Sylvain Richard, Gladys Massiera, Pascal Chanez, et al.

\section{To cite this version:}

Aurélie Petit, Lucie Knabe, Kamel Khelloufi, Myriam Jory, Delphine Gras, et al.. Reply to: Altered Calcium in Ciliary Dysfunction: Potential Role of ER Stress and Ciliophagy. American Journal of Respiratory Cell and Molecular Biology, 2019, 61 (6), pp.795-796. 10.1165/rcmb.2019-0263LE . hal02384626

\section{HAL Id: hal-02384626 \\ https://hal.science/hal-02384626}

Submitted on 18 Jun 2020

HAL is a multi-disciplinary open access archive for the deposit and dissemination of scientific research documents, whether they are published or not. The documents may come from teaching and research institutions in France or abroad, or from public or private research centers.
L'archive ouverte pluridisciplinaire HAL, est destinée au dépôt et à la diffusion de documents scientifiques de niveau recherche, publiés ou non, émanant des établissements d'enseignement et de recherche français ou étrangers, des laboratoires publics ou privés. 


\section{Reply to: Altered Calcium in Ciliary Dysfunction: Potential Role of ER Stress and Ciliophagy}

\section{From the Authors:}

We thank McAlinden and colleagues for their very interesting comments on our paper (1). In our study, we demonstrated the involvement of ORAI3 (ORAI calcium release-activated calcium modulator 3) in calcium signaling impairment in airway epithelia from smokers and patients with chronic obstructive pulmonary disease (COPD), and highlighted the role of ORAI 3 in regulating ciliary beating. McAlinden and colleagues propose that an improved understanding of cilia dysfunction could be greatly beneficial in the development of new therapies targeting mucociliary clearance, especially in airway diseases like COPD. They also propose that autophagy, and more specifically ciliophagy, could explain the dysfunctional cilia observed in COPD. Moreover, they suggest that a potential interplay among calcium homeostasis, autophagy in ciliated cells, and cilia shortening could play a role in COPD pathogenesis.

Autophagy is a cellular process that maintains cell function by degrading and recycling cellular constituents. Autophagy is crucial for cell growth and differentiation, innate and adaptive immunity, tumor suppression, life-span extension, and cell death, throughout cell life. In human diseases, there is increasing evidence that autophagy is associated with either pathogenic or protective effects. Many studies have demonstrated dysregulated autophagy in COPD. In addition to general autophagy, several studies suggested that selective autophagy may occur in COPD. Indeed, goblet-cell autophagy is activated by IL-13, promoting mucin secretion and an oxidative stress response (2). Also, impaired mitophagy can contribute to COPD pathogenesis (3). Moreover, ciliophagy, as highlighted by McAlinden and colleagues' letter, may contribute to COPD through cilia shortening (4). In brief, these different forms of autophagy are deleterious and may contribute to COPD pathogenesis. Therefore, additional knowledge about autophagy mechanisms should facilitate the discovery of new targets for COPD therapy.

However, autophagy is not solely deleterious for all cell types. It is crucial for maintaining cells in optimal condition and might be necessary for the proper functioning of certain cell types. Indeed, a recent study demonstrated a role for late-stage autophagy proteins in the function of lung secretory club cells (5). These club cells are specific to distal bronchial airways and appear to serve a protective role within the epithelium by secreting antiinflammatory proteins (6). These cells are deficient in patients with COPD (6). The notion of targeting autophagy as a potential therapy should be addressed, but it is likely that the highly inflammatory environment in the lungs of patients with COPD depresses autophagy in club cells. The controversial results in the literature with regard to whether autophagy is impaired or elevated in COPD should be further investigated and addressed according to cell specificity.

Author disclosures are available with the text of this letter at www.atsjournals.org.

Aurelie Petit, Ph.D.*

Hôpital Arnaud de Villeneuve

Montpellier, France

Lucie Knabe, Ph.D.

Hôpital Arnaud de Villeneuve

Montpellier, France

and

University of Montpellier

Montpellier, France

Kamel Khelloufi, Ph.D.

Aix Marseille University

Marseille, France

Myriam Jory, M.Sc.

Laboratoire Charles Coulomb (L2C)

Montpellier, France

Delphine Gras, Ph.D.

Aix Marseille University

Marseille, France 
Yann Cabon, Ph.D.

Montpellier University Hospital

Montpellier, France

Malcolm Begg, Ph.D.

GlaxoSmithKline

Stevenage, United Kingdom

Sylvain Richard, Ph.D.

University of Montpellier

Montpellier, France

Gladys Massiera, Ph.D.

Laboratoire Charles Coulomb (L2C)

Montpellier, France

Pascal Chanez, M.D., Ph.D.

Aix Marseille University

Marseille, France

Isabelle Vachier, Ph.D.

Hôpital Arnaud de Villeneuve

Montpellier, France

Arnaud Bourdin, M.D., Ph.D.

Hôpital Arnaud de Villeneuve

Montpellier, France

and

University of Montpellier

Montpellier, France

${ }^{\star}$ Corresponding author (e-mail: aurelie.fort@inserm.fr).

\section{References}

1. Petit A, Knabe L, Khelloufi K, Jory M, Gras D, Cabon Y, et al. Bronchial epithelial calcium metabolism impairment in smokers and chronic obstructive pulmonary disease: decreased ORAI3 signaling. Am J Respir Cell Moll Biol 2019;61: 501-504.

2. Dickinson JD, Alevy Y, Malvin NP, Patel KK, Gunsten SP, Holtzman MJ, et al. IL13 activates autophagy to regulate secretion in airway epithelial cells. Autophagy 2016;12: 397-409.

3. Mizumura K, Cloonan SM, Nakahira K, Bhashyam AR, Cervo M, Kitada T, et al. Mitophagy-dependent necroptosis contributes to the pathogenesis of COPD. J Clin Invest 2014;124: 3987-4003.

4. Lam HC, Cloonan SM, Bhashyam AR, Haspel JA, Singh A, Sathirapongsasuti JF, et al. Histone deacetylase 6-mediated selective autophagy regulates COPDassociated cilia dysfunction. J Clin Invest 2013;123:52125230.

5. Malvin NP, Kern JT, Liu TC, Brody SL, Stappenbeck T. Autophagy proteins are required for club cell structure and function in airways. Am J Physiol Lung Cell Mol Physiol 2019;317: L259-L270.

6. Gamez AS, Gras D, Petit A, Knabe L, Molinari N, Vachier I, et al. Supplementing defect in club cell secretory protein attenuates airway inflammation in COPD. Chest 2015;147: 1467-1476. 